\title{
Abnormális STAT1 aktivitás pikkelysömörben
}

\section{Abnormal STAT1 activation in psoriasis}

\author{
GUBÁN BARBARA ${ }^{1}$, KUI RÓBERT DR. ${ }^{1}$, KÉPÍRÓ LÁSZLÓ DR. ${ }^{1}$, BEBES ATTILA DR. ${ }^{1}$, \\ GROMA GERGELY DR. ${ }^{1}$, KEMÉNY LAJOS DR. ${ }^{1,2}$, BATA-CSÖRGÓ ZSUZSANNA DR. ${ }^{1,2}$
}

Szegedi Tudományegyetem, Bőrgyógyászati és Allergológiai Klinika, Szeged, Magyarország MTA-SZTE Dermatológiai Kutatócsoport, Szeged, Magyarország²

\section{ÖSSZEFOGLALÁS}

A STAT (signal transducer and activator of transcription) jelátviteli útvonalak kulcsfontosságú szerepet töltenek be a pikkelysömör patomechanizmusában. Kutatócsoportunk megállapította, hogy a STAT1 aktivált állapotban van egészséges és tünetes börben, ellentétben a tünetmentes börrel, ahol jórészt inaktív. Tünetmentes börben a csökkent mértékü STAT1 aktiváció független a lézióktól való távolságtól. Az aktivált STAT1 korrelációt mutat a PASI (psoriasis area and severity index) értékével, minél magasabb a beteg PASI-ja, annál erösebb az aktivált STAT1 kifejeződése a börben. Korábbi vizsgálataink azt mutatták, hogy a STAT1 abnormálisan regulálódik a pikkelysömörös fibroblasztokban. Ezek az eredmények felvetik annak lehetöségét, hogy a STAT1 új terápiás célpont lehet a betegségben.

\section{Kulcsszavak: pikkelysömör - STAT1 - tünetmentes bőr}

\section{SUMMARY}

The STAT (signal transducer and activator of transcription) signalling pathway plays a key role in the pathogenesis of psoriasis. Our results indicate that STAT1 is active in both healthy and in psoriatic lesional skin and in contrast to the non-lesional skin where it is mainly inactive. The distance from the lesion does not affect STAT1 activity in the non-lesional skin. The STAT1 activation correlates with the PASI (psoriasis area and severity index) of psoriatic patients. In our previous work we have shown that STAT1 is abnormally regulated in psoriatic fibroblasts. These data indicate that STAT1 could be a potential new target for the therapy of the disease.

\section{Key words: psoriasis - STAT1- non-lesional skin}

A pikkelysömör egy multifaktoriális, krónikus bőrbetegség, amelynek kialakulásában és fenntartásában mind a veleszületett, mind az adaptív immunitás szerepet játszik (1). A pikkelysömörös bőrben az epidermális keratinociták túlzott proliferációja és abnormális differenciációja figyelhetô meg, mely megvastagodott epidermiszt, csökkent vagy hiányzó granuláris réteget eredményez. Emellett fokozottan infiltrálódó T-limfociták, neutrofilek és leukociták, emelkedett növekedési faktor, citokin és kemokin kifejeződés figyelhető meg pikkelysömörös tünetes bőrben a celluláris immunrendszer aberráns aktivációjának köszönhetően (2-4). A makroszkópikusan normális fenotípust mutató, tünetmentes pikkelysömörös bőr - saját és más kutatócsoportok eredményei szerint különbözô eltéréseket hordoz magában az egészségeshez képest $(5,6)$.

A kutatások szerint a pikkelysömör patogenezisében kulcsfontosságú szerepet töltenek be a JAK (Janus kináz)
- STAT (signal transducer and activator of transcription) jelátviteli útvonalak, amelyek transzkripciós faktorai abnormális expressziót és aktivációt mutatnak, ezzel hozzájárulnak a pikkelysömör gyulladásos folyamatainak kialakulásához (7, 8). A különbözô JAK-ok (JAK1, JAK2, JAK3, Tyk2) eltérô STAT fehérjékkel tudnak kapcsolatba lépni. A STAT család 7 egymással nagyfokú homológiát mutató tagból áll (STAT 1, 2, 3, 4, 5a, 5b és 6), specifikus aktivitást mutatnak, így a funkciójuk széles skálája figyelhető meg a JAK-STAT jelátviteli útvonalakon keresztül (9, 10). Számos gént képesek aktiválni, míg másokat gátolni, ezáltal hatással vannak olyan alapvetô celluláris folyamatokra, mint a sejtproliferáció és -differenciáció, a sejttúlélés, az apoptózis, a migráció és az angiogenezis (9). Aktivációjuk és deaktivációjuk precízen irányított, néhány óra alatt lezajló folyamat (11).

A STAT1 aktiválódása az interferon (IFN) két különbözô típusa, az IFN $\alpha$ és az IFN $\gamma$ által valósul meg, ame-

Levelezô szerzô: Gubán Barbara

e-mail: gubanbarbi@gmail.com 
lyek a JAK1, JAK2 vagy Tyk2 dimerizációját és autofoszforilációját okozzák (10, 12). A JAK-ok kialakult specifikus kötőhelyeihez kapcsolódó STAT1 molekulák foszforilálódnak, ezáltal aktiválódnak, és homovagy heterodimer formában a sejtmagba transzlokálódnak, ahol növelik számos, az immunfolyamatok szabályozásában részt vevő gén transzkripcióját, így több, mint 65 gén expressziója fokozódik, amely körülbelül a pikkelysömörben eltérô szinten expresszálódó gének 5\%-át teszi ki $(2,13,14)$. A STAT1 aktivációjához mind a $\operatorname{Tyr}(701)$, mind a Ser(727) aminosav foszforilációja szükséges. A Tyr701 foszforiláció elengedhetetlen a STAT1 dimerizációjához, míg a Ser(727) a DNSkötő affinitásért és a sejtmagba történố transzlokalizációért, ily módon az aktivitás kialakulásáért felelős $(15,16)$.

Korábban Hald és munkatársai leírták az aktivált STAT1 kifejeződését pikkelysömörös tünetes bốrben (17). Kutatócsoportunk megállapította, hogy a STAT1 aktív állapotban van jelen az egészséges és a pikkelysömörös tünetes bőrben egyaránt, ellentétben a tünetmentes bórrel, ahol jórészt inaktív formában található (18). Jelen vizsgálatok a pikkelysömörös bőr STAT1 aktivitásának részletesebb vizsgálatát célozták meg.

\section{Anyagok és módszerek}

\section{Punch biopsziák}

Három középsúlyos-súlyos plakk típusú pikkelysömörös beteget és három egészséges donort vontunk be a vizsgálatba a 18-60 éves korosztályból. A $6 \mathrm{~mm}$-es punch biopsziák vétele kezelés nélküli időszakban történt, legalább 4 héttel a szisztémás vagy lokális kezelést követóen. A PASI (psoriasis area and severity index) értékét minden betegnél bórgyógyász határozta meg. A tünetmentes területekről közvetlenül a lézió mellől (tünetmentes közeli) és a plakktól $10 \mathrm{~cm}$-re (tünetmentes távoli) vettünk mintákat. A szöveti minták gyújtése eleget tett a Helsinki deklarációnak és a Népegészségügyi Szakigazgatási Szerv szabályainak $(2799,3517)$.

\section{Immunhisztokémiai festés}

A punch biopsziákat paraffinba ágyaztuk és szobahőmérsékleten tároltuk, majd 5 um vastagságú metszeteket készítettünk. A metszeteket deparaffináltuk és leszálló alkoholsort alkalmazva rehidratáltuk a mintákat, ezt követôen pH 6-os citrát pufferrel tártuk fel 95 ${ }^{\circ} \mathrm{C}$-on 10 percig. A metszeteket 20 percig $0,1 \% \mathrm{H}_{2} \mathrm{O}_{2}$-ot és $0,6 \%$ $\mathrm{NaN}_{3}$-ot (Sigma-Aldrich) tartalmazó PBS-sel, majd 30 percig kecske szérumot tartalmazó pufferrel (Invitrogen/ Thermo Fisher Scientific) blokkoltuk. Ezt követôen pSTAT1 Ser(727) és pSTAT1 Tyr(701), (mindkettő 1:400 hígításban, Cell Signaling Technology)
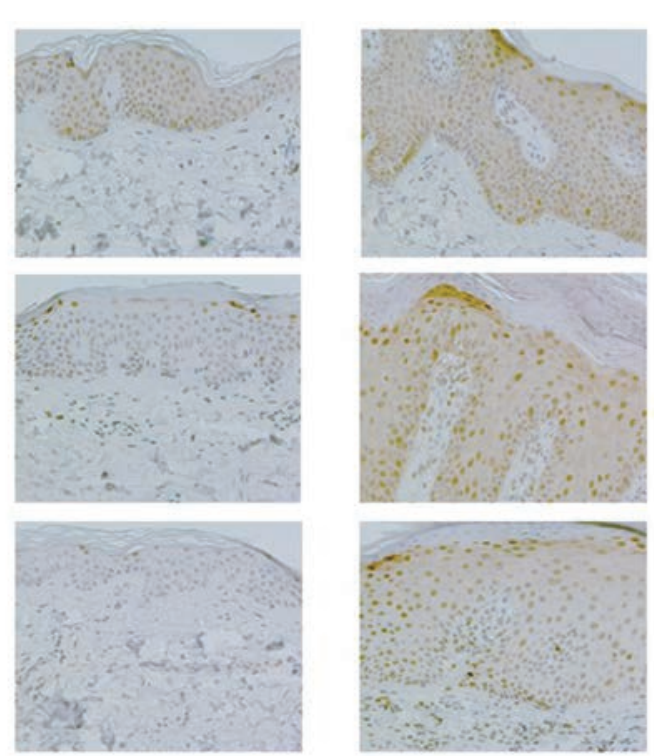

tünetes

\section{1. ábra}

munhisztokémiai festéssel vizsgálva a pSTAT1 Ser(727) formája nagyfokú míg tünetmentes bőrben szinte alig detektálható. A magas PASI-jú betegek ár tartalmaz aktivált STAT1-et, ellentétben az alacsony PASI-jú tünetmentes bőrrel $(\mathrm{n}=3)$

elsődleges ellenanyagokkal egész éjszakán át $4^{\circ} \mathrm{C}$-on inkubáltuk. A metszeteket PBS-ben mostuk, majd biotinilált kecske anti-nyúl ellenanyaggal inkubáltuk szobahốmérsékleten 30 percig (1:300, DAKO An Agilent Technologies Company). Újabb PBS-es mosást követôen streptavidin/biotin komplexszel (ABC kit, Enzo Life Sciences Inc.) inkubáltuk 20 percig. Negatív festési kontrollként elsődleges ellenanyag nélküli, csupán PBS-sel inkubált mintát használtunk. Az előhívást 3,3'-diaminobenzidin-nel (DAB) végeztük. A sejtmag és a citoplazma festése hematoxilin-eozinnal (SigmaAldrich) történt.

\section{Eredmények}

A paraffinos mintákon immunhisztokémiai festéssel vizsgált pSTAT1 Ser(727) forma kifejezôdése mind az epidermiszben, mind a dermiszben megfigyelhetô (1. ábra). A STAT1 aktivitása korrelál a PASI értékével; magas PASI esetén (pl. 19,6) a tünetes bőrben intenzívebb STAT1 kifejeződés tapasztalható, és ezeknél az eseteknél a tünetmentes bőr is kismértékú STAT1 aktivitást mutat, míg alacsony PASI-val bíró betegek (pl. 9,8) esetében ez nem volt megfigyelhető. Tünetmentes bőrben a pSTAT1 Ser(727) forma kifejeződése és a betegek PASI értéke párhuzamos csökkenést mutat. A pSTAT1 Tyr(701) formájának aktivációja nagyon gyorsan lezajlik, ezért csak magas PASI-jú betegek mintáin figyelhető meg, ahol 


\begin{tabular}{|c|c|c|c|c|c|c|c|c|c|c|c|c|c|}
\hline \multirow[b]{3}{*}{ BETEG } & \multirow[b]{3}{*}{ PASI } & \multicolumn{6}{|c|}{ pSTAT1 (Ser 727) } & \multicolumn{6}{|c|}{ pSTAT1 (Tyr701) } \\
\hline & & \multicolumn{2}{|c|}{ TM (távoli) } & \multicolumn{2}{|c|}{ TM (közeli) } & \multicolumn{2}{|c|}{$\mathbf{T}$} & \multicolumn{2}{|c|}{ TM (távoli) } & \multicolumn{2}{|c|}{ TM (közeli) } & \multicolumn{2}{|c|}{$\mathbf{T}$} \\
\hline & & $\mathbf{E}$ & D & $\mathbf{E}$ & D & $\mathbf{E}$ & D & $\mathbf{E}$ & D & $\mathbf{E}$ & D & $\mathbf{E}$ & D \\
\hline 1 & 19,6 & + & + & + & - & + & + & - & - & $+1-$ & $+/-$ & - & - \\
\hline 2 & 12,4 & $+1-$ & $+1-$ & $+1-$ & $+1-$ & + & + & - & - & - & - & - & - \\
\hline 3 & 9,8 & - & - & - & - & + & + & - & - & - & - & - & - \\
\hline
\end{tabular}

1. táblázat

A táblázat a pSTAT1 Ser(727) és a pSTAT1 Tyr(701) formák aktivációját mutatja tünetmentes és tünetes bőr epidermiszében és dermiszében, hozzárendelve a 3 vizsgált pikkelysömörös beteg PASI értékeit. TM: tünetmentes, T: tünetes, E: epidermisz, D: dermisz; +: erôs pozitivitás, +/-: gyenge pozitivitás, -: negatív

mindkét foszforilációs forma aktivációja jóval intenzívebb (1. táblázat). Összehasonlítotva a tünetmentes lézióhoz közeli és attól távoli területekrôl vett punch biopsziák pSTAT1 formáinak kifejeződését, megfigyelhető, hogy a STAT1 aktivitása független a lézióktól való távolságtól $(\mathrm{n}=3)$ (1. ábra). Az ábrán az is látható, hogy a STAT1 aktiváció legerősebben a pikkelysömörös tünetes bőrben mutatható ki. Bár a tünetmentes bőrben a STAT1 jórészt inaktív, aktivációja magas PASI érték esetén már az egészséges bőrben tapasztalthoz hasonló mértéket mutat.

\section{Megbeszélés}

Jelenleg a legtöbb kutatás pikkelysömörben a JAKSTAT jelátviteli útvonal köré csoportosul. A STAT család tagjai többféle funkciót töltenek be a veleszületett immunitásban. A STAT1 az IFN, az IL-27, az IL-35 és a TLR közvetített jelátvitelen keresztül aktiválódik (19). Számos tanulmány beszámol az IFN $\gamma$ jelátvitel fontosságáról a pikkelysömör patomechanizmusában (20). A STAT1 számos gén transzkripciós aktivációját okozza, míg más gének expresszióját antagonista módon befolyásolja, így kialakítva egy komplex szignál választ (21). Pikkelysömörös keratinocitákban a STAT1, az IRF1 (interferon regulated factor 1) és a SOCS1 (az IFN $\gamma$ szignaling negatív regulátora) transzkripciós faktorok aberráns regulációja kontrollálatlan növekedéshez és differenciációhoz vezethet $(7,22)$.

Kutatócsoportunk korábbi eredményei azt mutatták, hogy az egészséges egyének bőréből származó tenyésztett fibroblasztokban az aktivált STAT1 szükséges a fibronektin (FN1) és az onkofötális fibronektin $\left(\mathrm{EDA}^{+} \mathrm{FN}\right)$ termelés gátlásához, és a STAT1 gátlása fokozott FN1 és $\mathrm{EDA}^{+} \mathrm{FN}$ kifejeződést eredményez normál humán fibroblasztokban. Pikkelysömörös fibroblasztokban ezzel ellentétben nem figyelhető meg az aktivált STAT1 FN1 és $\mathrm{EDA}^{+} \mathrm{FN}$ kifejeződést gátló funkciója (18). Eredményeink alapján feltételezhető, hogy a pikkelysömörös bőrben leírt fokozott FN és EDA ${ }^{+}$FN kifejeződés $(6,23)$ hátterében részben a STAT1 abnormális funkciója állhat. Az aktivált STAT1 kifejezôdése a normál bőrben arra utal, hogy a szövet homeosztatikus állapotának fenntartásában a STAT1 aktiváció szerepet játszik. Az a tény, hogy a tünetmentes bőrben a STAT1 jórészt inaktivált állapotban van jelen, szintén a STAT1 aberráns múködésére utal a betegségben.
A JAK-STAT jelátviteli útvonal proinflammatorikus folyamatainak gátlása kulcsfontosságú lehet az immun-mediált bőrbetegségek patogenezisében. Hármas fázisú klinikai vizsgálatok folynak kis molekulájú JAK gátlók (tofacitinib, ruxolitinib) potenciális terápiaként való hatékony és biztonságos alkalmazhatóságának megítélésére a pikkelysömör kezelésében. Az I. és II. fázis tanulmányok eredményei dózisfüggő javulást mutattak a pikkelysömörös léziók súlyosságának mértékében a placebo csoporthoz viszonyítva. Számos STAT inhibitorról beszámoltak az irodalomban (24), azonban STAT1 gátlót még csak állatmodellekben használtak. Wagner és munkatársai hapten-indukálta kontakt hiperszenzitivitást gátoltak STAT1 decoy oligodeoxynukleotidot (dODN) tartalmazó krémmel (25).

Eredményeink arra engednek következtetni, hogy a STAT1 molekula kulcsfontosságú lehet a pikkelysömörre való hajlam kialakításában. A pathomechanizmusban betöltött szerepének pontos felderítése további vizsgálatokat kíván.

A munka elvégzéséhez az OTKA K83277, K105985, K111885, NK105369, PD116992, TÁMOP-4.2.4.A/2-11-1/2012-0001 és A2SZGYA-FOK-13-0001 pályázatok nyújtottak segítséget.

\section{IRODALOM}

1. Bos J.D., de Rie M. A., Teunissen M. B. et al: Psoriasis: dysregulation of innate immunity. Br. J Dermatol. (2005) 152, 10981107.

2. Krueger J. G., Bowcock A.: Psoriasis pathophysiology: current concepts of pathogenesis. Ann Rheumat Dis (2005) 64 Suppl 2, ii30-36.

3. Lowes M. A., Bowcock A. M., Krueger J. G.: Pathogenesis and therapy of psoriasis. Nature (2007) 445, 866-873.

4. Nograles K. E., Davidovici B., Krueger J. G.: New insights in the immunologic basis of psoriasis. Seminars in cutaneous medicine and surgery (2010) 29, 3-9.

5. Pellegrini G., De Luca M., Orecchia G. et al.: Expression, topography, and function of integrin receptors are severely altered in keratinocytes from involved and uninvolved psoriatic skin. J Clin Invest (1992) 89,1783-1795.

6. Bata-Csorgo Z., Cooper K. D., Ting K. M. et al.: Fibronectin and alpha5 integrin regulate keratinocyte cell cycling. A mechanism for increased fibronectin potentiation of $\mathrm{T}$ cell lymphokinedriven keratinocyte hyperproliferation in psoriasis. J Clin Invest (1998) 101, 1509-1518.

7. McKenzie R. C., Sabin E.: Aberrant signalling and transcription factor activation as an explanation for the defective growth control and differentiation of keratinocytes in psoriasis: a hypothesis. Exp Dermatol (2003) 12, 337-345. 
8. van der Fits L., van der Wel L. I., Laman J. D. et al.: In psoriasis lesional skin the type I interferon signaling pathway is activated, whereas interferon-alpha sensitivity is unaltered. J Invest Dermatol (2004) 122, 51-60.

9. Rawlings J. S., Rosler K. M., Harrison D. A.: The JAK/STAT signaling pathway. J Cell Sci (2004) 117, 1281-1283.

10. Darnell J. E. Jr.: STATs and gene regulation. Science (1997) 277 , 1630-1635.

11. Furqan M., Mukhi N., Lee B. et al.: Dysregulation of JAK-STAT pathway in hematological malignancies and JAK inhibitors for clinical application. Biomark Res (2013) 1, 5.

12. Igarashi K., Garotta G., Ozmen L. et al.: Interferon-gamma induces tyrosine phosphorylation of interferon-gamma receptor and regulated association of protein tyrosine kinases, Jak1 and Jak2, with its receptor. J Biol Chem (1994) 269, 14333-14336.

13. Ghoreschi K., Laurence A., O'Shea J.J.: Janus kinases in immune cell signaling. Immunol Rev (2009) 228, 273-287.

14. Shuai K., Liu B.: Regulation of JAK-STAT signalling in the immune system. Nat Rev Immunol (2003) 3, 900-911.

15. Decker T., Kovarik P.: Serine phosphorylation of STATs. Oncogene (2000) 19, 2628-2637.

16. Uddin S., Sassano A., Deb D. K. et al.: Protein kinase C-delta (PKCdelta ) is activated by type I interferons and mediates phosphorylation of Stat1 on serine 727. J Biol Chem (2002) 277, 14408-14416.

17. Hald A., Andres R. M., Salskov-Iversen M. L.: STAT1 expression and activation is increased in lesional psoriatic skin. Br. J Dermatol. (2013) 168, 302-310.

18. Guban B., Vas K., Balog Z. et al.: Abnormal regulation of fibronectin production by fibroblasts in psoriasis. Br J Dermatol 2015 Oct 15. doi: 10.1111/bjd.14219. [Epub ahead of print].
19. Lии K., Greenhill C. J., Majoros A. et al.: STAT1 plays a role in TLR signal transduction and inflammatory responses. Immunol Cell Biol (2014) 92, 761-769.

20. Albanesi C., Scarponi C., Giustizieri M. L. et al.: Keratinocytes in inflammatory skin diseases. Curr Drug Targets Inflamm Allergy (2005) 4, 329-334.

21. Ramana C. V., Chatterjee-Kishore M., Nguyen H. et al.: Complex roles of Stat 1 in regulating gene expression. Oncogene (2000) 19, 2619-2627.

22. Madonna S., Scarponi C., Sestito R. et al.: The IFNgamma-dependent suppressor of cytokine signaling 1 promoter activity is positively regulated by IFN regulatory factor- 1 and Sp1but repressed by growth factor independence-1b and Krüppel-like factor-4, and it is dysregulated in psoriatic keratinocytes. J Immunol (2010) 185, 2467-2481.

23. Ting K. M., Rothaupt D., McCormick T. S. et al.: Overexpression of the oncofetal Fn variant containing the EDA splice-in segment in the dermal-epidermal junction of psoriatic uninvolved skin. J Invest Dermatol (2000) 114, 706-711.

24. Nelson E. A., Sharma S. V., Settleman J. et al.: A chemical biology approach to developing STAT inhibitors: molecular strategies for accelerating clinical translation. Oncotarget (2011) 2, 518-524.

25. Wagner A. H., Wittjen I., Stojanovic T. et al.: Signal transducer and activator of transcription 1 decoy oligodeoxynucleotide suppression of contact hypersensitivity. J Allergy Clin Immunol (2008) $121,158-165$ e5.

Érkezett: 2016. 01. 11.

Közlésre elfogadva: 2016. 01. 18.

\section{Hazai Hírek}

Az MDT Kontakt Dermatitis Munkacsoport 2015. évi ülését a Magyar Dermatológiai Társulat Nagygyúlésén november 28-án tartotta meg.

Az MDT 88. Tudományos Ülésén önálló szekcióban elhangzott előadások: a fogászati kontakt allergének tesztelési lehetôségeirôl ( $d r$. Baló Mátyás), az állati szôrök okozta kontakt szenzibilizációk diagnosztikus nehézségéről, klinikumáról ( $r$ r. Nagy Gabriella), a hajfestékek okozta igen erôs, hospitalizációs kezelésre szoruló kontakt szenzibilizációiról (dr. Koller Ágnes Hanna), az MI és a Katon CG szenzibilizáció aktuális adatairól ( $d r$. Pónyai Györgyi), a higany allergia jelenleg is tapasztalható gyakorlati jelentőségérôl (dr. Fábos Beáta) szóltak.

A kontakt szenzibilizáció tesztelésének értékelési idejére vonatkozó (hazánkban 2007-től alkalmazott) metodikai előírásairól önálló előadás hangzott el, hivatkozva az ezzel megegyező 2015 novemberében megjelent európai guideline előírásaira, kiemelve a 7., alkalmanként a 10 napig javasolt tesztreakció követést. Az előadó részletezte az epicutan próbák okozta - elenyészőnek mondható - mellékhatások lehetôségeit, ezek megelôzésében hangsúlyozta a standard metodika és standard tesztanyagok előnyeit (dr. Temesvári Erzsébet).

A szekció ülést követően a Munkacsoport az elmúlt év multicentrikus vizsgálatát beszélte meg, melynek során a hazai epicutan sorba bevezetett methilizotiazolin (MI) tesztelés eredményeit értékelte.

A Munkacsoport felhívta a figyelmet a 2007-tôl alkalmazott hazai tesztelési metodikának megfelelő európai guideline (Contact Dermatitis 2015. 73,195) epicutan teszt értékelés kritériumára, mely szerint a bőrtesztek értékelése 20-60 perc, 48 óra, 72 vagy 96 óra és a 7. nap. Hangsúlyozta az egységes tesztelési metodika jelentőségét a kiadott teszteredmények - alkalmanként szükséges - szakvéleményezésében.

A Munkacsoport a Magyar Sor antigénjeit - melyek jelenleg európai guidelinenek megfelelnek - nem bővítette.

Budapest, 2015. november 30.

Prof. Dr. Temesvári Erzsébet

egyetemi tanár, a Munkacsoport vezetôje 